Хмарська І. А., к.е.н., доцент

Національний університет кораблебудування імені адмірала Макарова м. Миколаїв, Україна

DOI: https://doi.org/10.30525/978-9934-26-018-6-19

\title{
РИНОК МАРКЕТИНГОВИХ КОМУНІКАЦІЙ ТА ТЕНДЕНЦЇ̈ ЙОГО РОЗВИТКУ
}

У кризові періоди, як ніколи, чітко усвідомлюється факт того, що суспільство увійшло в епоху економіки відносин, а стійкість бізнесу безпосередньо пов'язана з його репутацією. Міжнародні фінансові рейтинги корпорацій і держав, їх кредитоспроможність та інвестиційна привабливість більшою мірою грунтуються на оцінках експертів, приватних інвесторів, журналістів і блогерів, ніж на фінансових даних. 3 одного боку, таке оцінювання, безумовно, багато в чому є суб'єктивним, а $з$ іншого, - схильна до маніпуляцій так само, як і громадська думка. I чим більшу роль у бізнес-процесах набувають відносини між гравцями, тим швидше зростає вплив комунікацій в економіці. Фінансові показники бізнесу все більше і більше залежать від того, як він вибудовує свої комунікації із зовнішнім середовищем.

Для того, щоб зрозуміти, які саме інструменти маркетингових комунікацій мають бути задіяними для формування комплексу маркетингових комунікацій на різних рівнях партнерських відносин, необхідно розглянути стан та тенденції розвитку сучасного ринку маркетингових комунікацій.

Пропонуємо це зробити за двома напрямами: провести аналіз ринку маркетингових комунікацій за останні роки та визначити тенденції його розвитку; дослідити інновації на ринку маркетингових комунікацій і визначити сучасні комунікативноінформаційні тренди.

Слід зазначити, що на сьогодні поняття «ринок маркетингових комунікацій» застосовується як таке, що не потребує визначення. Причому деякі дослідники [1] ототожнюють його 3 ринком 
реклами, деякі з ринком комунікаційних послуг, частина авторів просто використовує це поняття без усіляких пояснень [2].

Якщо говорити про ринок комунікаційних послуг, то це поняття $€$ значно ширшим, ніж ринок маркетингових комунікацій, бо включає в себе всі види комунікацій, у тому числі й ті, в рамках яких здійснюється фізичне переміщення осіб і товарів.

Використання цього терміну без належної інтерпретації, ставить під сумнів об'єктивність проведених досліджень, бо досліджується невизначений об'єкт.

Тому насамперед окреслимо коло науково-практичних узагальнень, які визначатимуть ринок маркетингових комунікацій.

3 найбільш наближених визначень до ринку маркетингових комунікацій $є$ визначення рекламного ринку. Згідно визначення Всеукраїнської рекламної коаліції (ВРК) та Міжнародної Асоціації Маркетингових Ініціатив (МАМI): «Рекламний ринок це поняття, що означає комплекс попиту на рекламні послуги (рекламодавці) і конкурентних пропозицій, які задовольняють попит на ці послуги (рекламні, маркетингові, медіа та інші агенції, а також ЗМІ та інші рекламоносії)».

Нині ринок комунікацій є розвиненим сегментом економіки багатьох країн світу і включає широку систему економічних, правових, соціокультурних i інших відносин, які виникають i розвиваються між основними суб'єктами цього ринку рекламодавцями, виробниками реклами, розповсюджувачами i споживачами комунікацій. Між ними існує тісний економічний взаємозв'язок, який є основою функціонування ринку в цілому [2].

Стан ринку маркетингових комунікацій у рамках тієї чи іншої економіки безпосередньо залежить від загальноекономічної ситуації в країні, тому комунікаційна активність на ринку іноді розглядається як своєрідний індикатор економічного розвитку. 3 іншого боку, усвідомлення процесів та тенденцій в кожній окремій галузі національної економіки може бути своєрідним джерелом знань для подальшого планування розвитку економіки в цілому. 
Проведемо аналіз ринку маркетингових комунікацій у розрізі основних мас-медіа.

ТБ-реклама. Телебачення є не тільки провідним рекламоносієм, не лише найбільшим інвестором в медіа контент, який, власне, і впливає на медіа споживання і на наявність споживчої аудиторії, на зустрічі 3 якою сподівається рекламодавець. Телебачення виступає драйвером багатьох процесів, що відбуваються на медіа ринку взагалі - від правового поля і структури ринку до креативного змісту рекламного повідомлення [3].

Зокрема, виділення «відео-реклами» в якості окремого напряму Інтернет-реклами є заслугою телебачення, яке «поставляє» значну частину відеоконтенту (професійного, чи не користувальницького) в мережу. Експерти прогнозують, що всі еволюційні i, можливо, революційні зміни в майбутньому рекламної індустрії будуть або ініційовані, або пов'язані саме з телебаченням.

Реклама в пресі. Насамперед, зауважимо, що не всі учасники ринку розуміють, які саме комунікації враховуються в цьому сегменті ринку. Деякі дослідники мають на увазі під «рекламою в пресі» виключно «друковану рекламу» (рекламні макети в газетах і журналах). Навпаки, інші фахівці підсумовують всі рекламні доходи видавничих будинків, включаючи мобільні версії (додатки) видань або сайти.

ВРК разом 3 експертною радою (Української Асоціації Видавців (УАВПП) (в експертну раду входять видавці та рекламні агентства) при визначенні обсягів реклами в пресі оцінює як «традиційні» друковані рекламні макети, так і різні «нестандартні», точніше, «немакетні» форми рекламного просування за допомогою друкованих видань: спонсорські проекти, вкладки, спеціальні рубрикатори тощо [4]. При цьому головне правило - реклама має бути пов'язана 3 «фізичним» зразком видання, а не інтернет (digital) версією. Доходи ж від реклами в мобільних додатках, на сайтах видань враховуються при підрахунку Інтернет-реклами і не входять в сегмент Реклами в пресі. 
Оператори IndoorVideo говорять про те, що клієнти частіше цікавляться нестандартними рішеннями. Серед таких запитів щоденне оновлення контенту, гнучкий показ в одному часовому блоці різних роликів від однієї торгової марки в комплексі зі статичними банерами. 3'являються запити інтерактивного контакту з аудиторією, коли рекламний носій закликає споживача зробити якусь дію і відразу ж відображає по ньому результати. Але поки істотну частку бюджету, який виділяється на цей канал комунікації зі споживачами, складають традиційні рекламні ролики із заданою частотою повторів.

Транспортна i Indoor реклама. Якщо 3 Digital частиною Транспорту та Індора все більш-менш зрозуміло - завдяки наявності профільної асоціації, то 3 рекламоносіями «доцифрової» ери ситуація $є$ менш очевидною. Дані про ці сегменти ринку отримані аналітичним шляхом і покликані показати, швидше, порядок рекламних інвестицій.

Оператори IndoorVideo говорять про те, що клієнти частіше цікавляться нестандартними рішеннями. Серед таких запитів щоденне оновлення контенту, гнучкий показ в одному часовому блоці різних роликів від однієї торгової марки в комплексі зі статичними банерами. 3'являються запити інтерактивного контакту з аудиторією, коли рекламний носій закликає споживача зробити якусь дію і відразу ж відображає по ньому результати. Але поки істотну частку бюджету, який виділяється на цей канал комунікації зі споживачами, складають традиційні рекламні ролики із заданою частотою повторів.

Підсумовуючи слід заначити, що за останній рік медіа реклама втратила 20\% свого об’єму у гривні, маркетингові сервіси та директ-маркетинг - близько 25-30\%, PR-індустрія в середньому втратила кожну п'яту-шосту гривню. Проте більшість гравців та експертів ринку маркетингових комунікацій налаштовані позитивно. Експерти сподіваються на найближчу стабілізацію і активне проведення реформ, що зможе простимулювати зростання економіки і створити сприятливі умови для розвитку [3]. Однак, беручи до уваги непрогнозованість політичної, а 
відтак, й економічної ситуації, очікування змін податкового законодавства та посилення фіскальної політики держави, неможна розраховувати на позитивні тенденції розвитку ринку маркетингових комунікацій у найближчі кілька років.

\section{Література:}

1. Яцишина Л.К., Волкович А.Р. Інноваційні технології в системі маркетингових комунікацій. Ефективна економіка. 2014. № 3. URL: http://www.economy.nayka.com.ua/?op=1\&z=2839.

2. Рижкова Г.А. Особливості і перспективи розвитку ринку маркетингових комунікацій в Україні. Економічний нобелівський вісник. 2014. № 1 (7). C. $375-381$.

3. Лазебник М. ВРК: Объем рекламно-коммуникационного рынка Украины 2013. URL: http://mmr.ua/news/id/vrk-obem-reklamno-kommunikacionnogo-rynkaukrainy-2013-37344.

4. Міжнародна асоціація маркетингових ініціатив. URL: http://www.mami.org.ua. 